\title{
Hanford Site Raptor Nest Monitoring Report for Calendar Year 2013
}

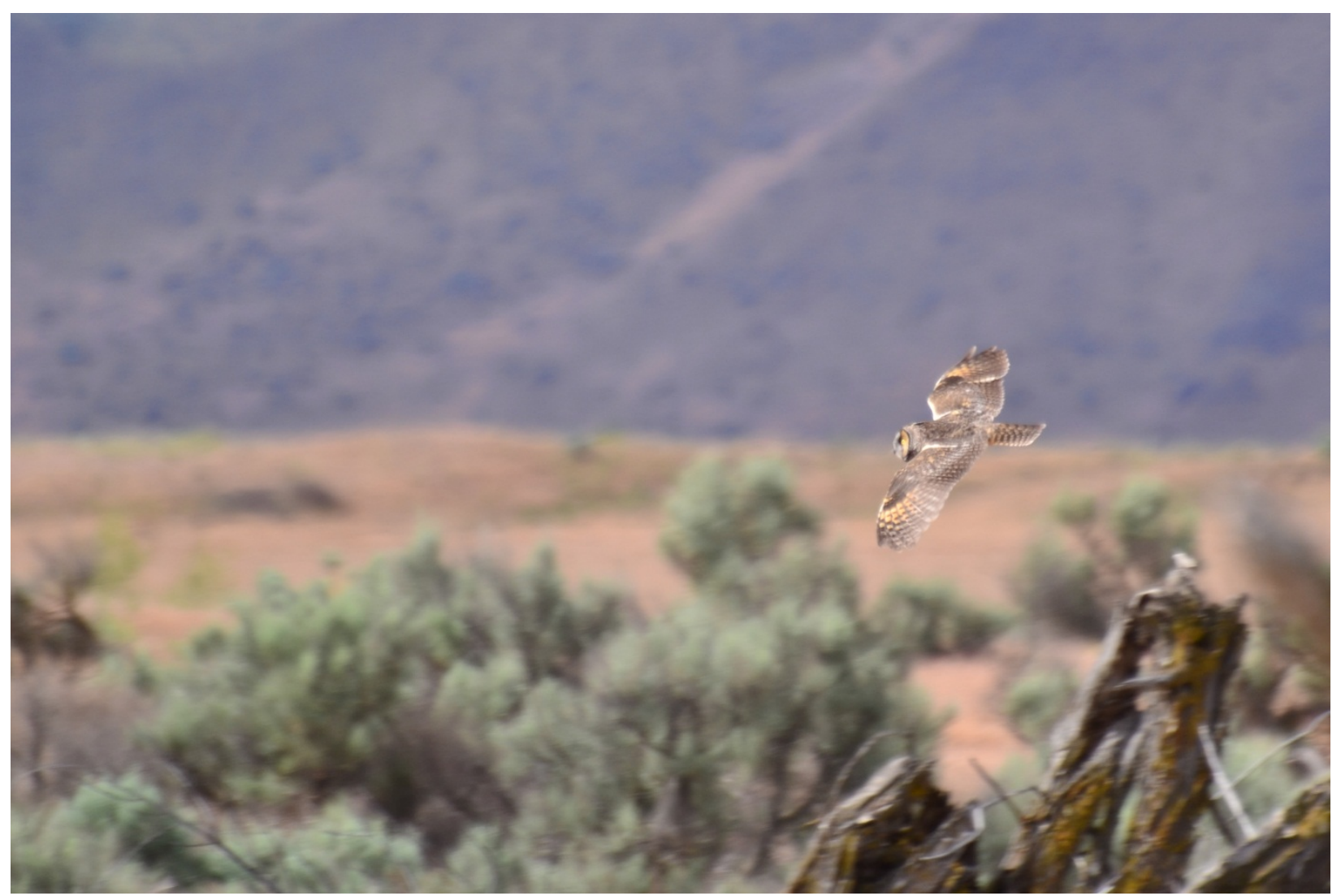

Prepared for the U.S. Department of Energy Assistant Secretary for Environmental Management Contractor for the U.S. Department of Energy under Contract DE-AC06-09RL14728

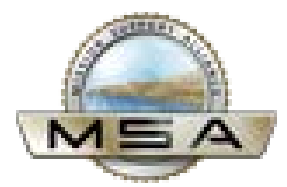

P.O. Box 650

Richland, Washington 99352 
HNF-56769

Revision 0

TRADEMARK DISCLAIMER

Reference herein to any specific commercial product, process, or service by trade name, trademark, manufacturer, or otherwise, does not necessarily constitute or imply its endorsement, recommendation, or favoring by the United States Government or any agency thereof or its contractors or subcontractors.

This report has been reproduced from the best available copy.

Printed in the United States of America

The cover photo is of a long-eared owl, courtesy of Cole Lindsey. 


\section{Hanford Site Raptor Nest Monitoring Report for Calendar Year 2013}

J. Nugent, C. Lindsey, J. Wilde Mission Support Alliance

Date Published

February 2014

Prepared for the U.S. Department of Energy

Assistant Secretary for Environmental Management

Contractor for the U.S. Department of Energy

under Contract DE-AC06-09RL14728

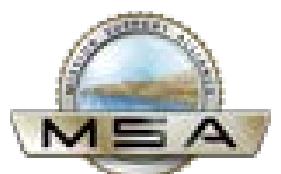

P.O. Box 650

Richland, Washington 99352

APPROVED

By Janis D. Aardal at 3:32 pm, Feb 13, 2014 


\section{Contents}

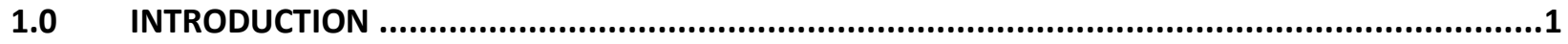

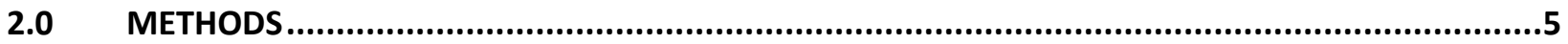

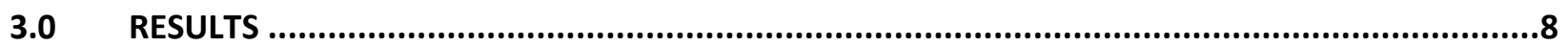

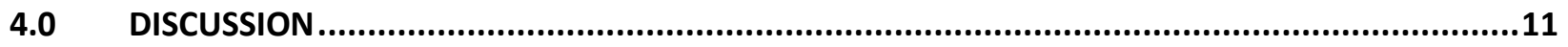

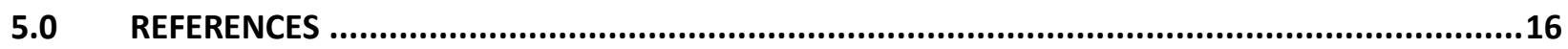

\section{Figures}

Figure 1. Area Surveyed for Raptor Nests on DOE-RL Managed Lands of the Hanford Site in 2013................. 6

Figure 2. Distribution of Nesting Substrates on DOE-RL Managed Lands of the Hanford Site .......................... 7

Figure 3. Raptor Nests Located on DOE-RL Managed Lands of the Hanford Site in 2013 ............................... 9

Figure 4. Common Raven Nests Located on DOE-RL Managed Lands of the Hanford Site in 2013 ................. 10

Figure 5. Number of Nest Sites by Raptor Species Located on DOE-RL Managed Lands of the Hanford

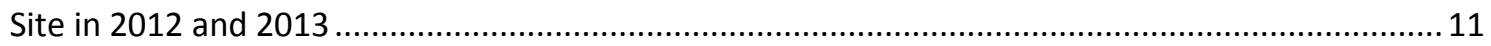

Figure 6. Two Young Bald Eagles in Nest Near Wooded Island, Hanford Site .............................................. 12

Figure 7. Young Long-eared Owls in Nest Northeast of 100-D Area, Hanford Site.......................................... 15

\section{Tables}

Table 1. Status of Nesting Raptors of the Hanford Site

Table 2. Nest Site Selection of Raptors on the Hanford Site and Likelihood of Detecting Nests during Annual Surveys..... 4

Table 3. First-egg Dates for Raptor Species Known to Nest on the Hanford Site 5

Table 4. Nest Substrates Used by Raptors and Ravens on DOE-RL Managed Lands of the Hanford Site in 2013. 
HNF-56769

Revision 0

\subsection{Introduction}

The U.S. Department of Energy, Richland Operations Office (DOE-RL) conducts ecological monitoring on the Hanford Site to collect and track data needed to ensure compliance with an array of environmental laws, regulations, and policies governing DOE activities. Ecological monitoring data provide baseline information about the plants, animals, and habitat under DOE-RL stewardship at Hanford required for decision-making under the National Environmental Policy Act (NEPA) and Comprehensive Environmental Response, Compensation, and Liability Act (CERCLA). The Hanford Site Comprehensive Land Use Plan (CLUP, DOE/EIS-0222-F) which is the Environmental Impact Statement for Hanford Site activities, helps ensure that DOE-RL, its contractors, and other entities conducting activities on the Hanford Site are in compliance with NEPA.

The Hanford Site Biological Resources Management Plan (BRMP, DOE/RL 96-32 Rev 1) is identified by the CLUP as the primary implementation control for managing and protecting natural resources on the Hanford Site. According to the CLUP, the BRMP

"provides a mechanism for ensuring compliance with laws protecting biological resources; provides a framework for ensuring that appropriate biological resource goals, objectives, and tools are in place to make DOE an effective steward of the Hanford biological resources; and implements an ecosystem management approach for biological resources on the Site. The BRMP provides a comprehensive direction that specifies DOE biological resource policies, goals, and objectives. "

DOE-RL places priority on monitoring those plant and animal species or habitats with specific regulatory protections or requirements; or that are rare and/or declining (federal or state listed endangered, threatened, or sensitive species); or of significant interest to federal, state, or tribal governments or the public. The BRMP ranks wildlife species and habitats (Levels $0-5$ ), providing a graded approach to monitoring biological resources based on the level of concern for each resource. The Ferruginous hawk (Buteo regalis) is a Washington State threatened species and a federal species of concern. Ferruginous hawks are ranked as Level 4 resources in the BRMP along with Bald Eagles (Haliaeetus leucocephalus) which are Washington State Sensitive and a federal species of concern. Level 4 resources require a high level of monitoring under the BRMP.

The Hanford Site supports a large and diverse community of raptorial birds (Fitzner et al. 1981), with 26 species of raptors observed on the Hanford Site. Thirteen raptor species have been recorded nesting on the Hanford Site, including eight species of diurnal raptors and five species of owls (Table 1). Several of these species are on state and federal threatened and endangered species lists (WDFW 2013). In addition to the Ferruginous hawks and Bald Eagles, the Burrowing Owl (Athene cunicularia) is a Washington State candidate species and a federal species of concern. Swainson's hawks (Buteo swainsoni), Prairie Falcons (Falco mexicanus), and Ospreys (Pandion haliaetus) are Washington State Monitored species. Because of the status of these species, it is important that DOE-RL documents nest 
locations to avoid disturbance during the nesting season and to track populations over time to determine impacts of Hanford operations on these species.

Table 1. Status of Nesting Raptors of the Hanford Site

\begin{tabular}{|l|l|c|c|}
\hline \multicolumn{1}{|c|}{ Species } & \multicolumn{1}{c|}{ Species Status } \\
\hline Ferruginous Hawk & \multicolumn{1}{|c|}{ Scientific Name } & Threatened & Species of Concern \\
\hline Swainson's Hawk & Buteo regalis & Monitored & None \\
\hline Red-tailed Hawk & Buteo swainsoni & None & None \\
\hline Prairie Falcon & Buteo jamaicenais & Monitored & None \\
\hline American Kestrel & Falco mexicanus & None & None \\
\hline Northern Harrier & Falco sparverius & None & None \\
\hline Bald Eagle & Circus cyaneus & Sensitive & Species of Concern \\
\hline Osprey & Haliaeetus leucocephalus & Monitored & None \\
\hline Great Horned Owl & Pandion haliaetus & None & None \\
\hline Long-eared Owl & Bubo virginianus & None & None \\
\hline Short-eared Owl & Asio otus & None & None \\
\hline Burrowing Owl & Asio flammeus & Candidate & Species of Concern \\
\hline Barn Owl & Athene cunicularia & None & None \\
\hline
\end{tabular}

The creation of the Hanford Site has likely benefited many raptor species, due to restrictions on public access, livestock grazing, and agriculture for the past 70 years. In addition, species such as American Kestrels (Falco sparverius), Great Horned Owls (Bubo virginianus), Long-eared Owls (Asio otus), Red-tailed hawks (Buteo jamaicenais), Swainson's hawks, Ferruginous hawks, and Bald Eagles have benefited from the trees that people planted near abandoned homesteads, townsites, and previous army encampment sites. Prior to European settlement, trees occurred only sporadically on the Hanford Site, along riparian zones. Human construction has also provided nesting habitat for a variety of raptors. Barn Owls (Tyto alba) have been found nesting in abandoned buildings on the Hanford Site. Red-tailed hawks, Swainson's hawks, and Ferruginous hawks have also benefited from the nesting habitat provided by transmission towers and wooden utility poles. Ospreys, which are recent additions to the list of nesting raptors on the Hanford Site, have benefited from nest platforms built for their use.

Some species of raptors nest on the Hanford Site in low numbers due to the natural lack of suitable nesting habitats, food sources, or nesting substrates. For instance, Prairie Falcons nest primarily on cliffs which, on the Hanford Site, are limited to Rattlesnake Mountain, Gable Mountain, Gable Butte, Yakima Ridge, and Umtanum Ridge. Northern Harriers (Circus cyaneus) nest primarily on the ground in wetland areas which are also limited on the Hanford Site. Ospreys are most likely limited by the lack of suitable nest sites and food sources. Ospreys subsist on live fish and consequently are restricted to areas along the Columbia River.

Short-eared Owls (Asio flammeus) are common winter visitors to the Hanford Site but rarely nest onsite. Short-eared owls nest on the ground in marshes, grasslands, and tundra areas supporting dense cyclic populations of small mammals (Wiggins et al. 2006). Short-eared Owls have been found nesting in the 
past around Benson Ranch on Fitzner/Eberhardt Arid Lands Ecology Reserve (Fitzner et al. 1981) but nowhere else onsite.

Bald Eagles occur on the Hanford Site primarily during the winter months when they congregate to feed on post-spawned fall Chinook salmon (Oncorhynchus tshawytscha) carcasses that wash up along the shores of the Columbia River, and waterfowl that winter in the area. While pairs of Bald Eagles do attempt to nest on the Hanford Site, most individuals leave the area in the spring, without successfully raising young, when their food sources diminish (USDOE 2009). However, in 2013, the first successful Bald Eagle nest was documented on the Hanford Site.

Surveys of nesting raptors have been conducted on the Hanford Site since 1973 by the DOE-RL and Washington Department of Fish and Wildlife (WDFW) (Olendorff 1973; Fitzner et al. 1977; Fitzner 1978, 1980, Fitzner et al. 1981; Poole et al. 1988; Fitzner and Newell 1989; Nugent 1995; Leary 1996; Dirkes and Hanf 1998; Leary et al. 1998; Dirkes et al. 1998, 1999; Poston et al. 2000, 2001; Clayton 2005). However, these surveys were not conducted systematically. The past surveys were not consistent in the area chosen for monitoring; some years included only the DOE-RL Managed portion of the Hanford Site, some years included either the entire Hanford Site or a portion of the Hanford Site, and some years only included known nest locations. The previous surveys were not conducted every year, and the species documented during previous surveys included different subsets of raptors. In 2012, a consistent and reproducible approach for long-term monitoring of nesting raptors was initiated for the portions of the Hanford Site managed by DOE-RL (Nugent et al. 2013).

The focus of this report is to document the distribution and abundance of nesting raptors on the DOE-RL managed portions of the Hanford Site. Annual surveys provide land managers with specific locations of nest sites so nests can be avoided and disturbances minimized during the nesting season. Long-term trends in nesting raptor populations also allow assessment of the possible impacts of Hanford Site operations.

The survey methods described in Section 2.0 are likely to detect the majority of species of nesting raptors on the Hanford Site but with varying degrees of success (Table 2). One exception is the Shorteared Owl which may not nest within the current survey area. The survey methods are likely to detect a majority of individual nest sites for Red-tailed hawks, Swainson's hawks, Ferruginous hawks, Prairie Falcons, Bald Eagles, Ospreys, Great Horned Owls, and Long-eared Owls. Some species nest in sites that are less conspicuous and a high proportion of individual nest sites for these species are not likely to be detected using these methods. For example, burrowing owls nest in burrows on the ground and the methods described here are not optimal for documentation of these nest sites (separate monitoring efforts were instituted for Burrowing Owls in 2012 and 2013). Northern Harriers and Short-eared Owls are ground nesting birds and their nests are difficult to detect, and are thus not likely to be accurately assessed using this methodology. American Kestrels are secondary cavity nesters and most nest sites are not detected using these survey methods. 
HNF-56769

Revision 0

Table 2. Nest Site Selection of Raptors on the Hanford Site and Likelihood of Detecting Nests during Annual Surveys

\begin{tabular}{|c|c|c|c|}
\hline Species & Nest Site Selection & $\begin{array}{l}\text { Likely to Detect Nests if } \\
\text { Present? }\end{array}$ & $\begin{array}{c}\text { Likely to Detect Most } \\
\text { Nests? }\end{array}$ \\
\hline Ferruginous Hawk & $\begin{array}{l}\text { Trees, Cliffs/Rock Outcrops, Utility } \\
\text { Structures }\end{array}$ & Yes & Yes \\
\hline Swainson's Hawk & $\begin{array}{l}\text { Primarily Trees, but also Utility } \\
\text { Structures }\end{array}$ & Yes & Yes \\
\hline Red-tailed Hawk & $\begin{array}{l}\text { Trees, Cliffs/Rock Outcrops, Utility } \\
\text { Structures }\end{array}$ & Yes & Yes \\
\hline Prairie Falcon & Primarily Cliffs & Yes & Yes \\
\hline American Kestrel & Primarily Secondary Cavities in Tree & Yes & No \\
\hline Northern Harrier & $\begin{array}{l}\text { Primarily on Ground in Wetland } \\
\text { Vegetation but also Dry Grasslands }\end{array}$ & No & No \\
\hline Bald Eagle & Large Trees, Nest Platforms, Cliffs & Yes & Yes \\
\hline Osprey & Large Trees, Nest Platforms, Cliffs & Yes & Yes \\
\hline Great Horned Owl & $\begin{array}{l}\text { Primarily in Trees in Nests Built by } \\
\text { Other Species }\end{array}$ & Yes & Yes \\
\hline Long-eared Owl & $\begin{array}{l}\text { Primarily in Trees in Nests Built by } \\
\text { Other Species }\end{array}$ & Yes & Yes \\
\hline Short-eared Owl & Primarily on Ground in Dry Sites & No & No \\
\hline Burrowing Owl & $\begin{array}{l}\text { Primarily in Burrows Dug by Other } \\
\text { Animals but also Human-made } \\
\text { Structures (e.g., Culverts, Artificial } \\
\text { Burrows) }\end{array}$ & Yes & No \\
\hline Barn Owl & $\begin{array}{l}\text { Existing Cavities in Trees, Cliffs/Rock } \\
\text { Outcrops, Caves, Buildings }\end{array}$ & Yes & Yes \\
\hline
\end{tabular}

The most conspicuous raptors nesting on the Hanford Site are the three species of Buteo hawks: the Red-tailed hawk, Swainson's hawk, and Ferruginous hawk. These species build large stick nests on trees, cliffs, rock outcrops, utility poles and transmission towers. The largest number of raptor nest sites detected with these methods will belong to Buteo hawks. Common Ravens (Corvus corax) also build large stick nests that are difficult to distinguish from Buteo hawk nests without the presence of birds. Common Ravens are not considered raptors but perform a similar ecological role. The majority of Common Raven nests are detected with these survey methods.

Raptor nesting season on the Hanford Site extends over six months, generally from March through August (Fitzner et al. 1981). Fitzner et al. (1981) found that Great Horned Owls were the earliest nesters on the Hanford Site, with an average egg laying date of March 15. American Kestrels were the last nesters with an average laying date of May 25. First-egg dates for raptor species known to nest on the Hanford Site are provided in Table 3. In order to detect the greatest number of raptor nests, surveys were conducted in late May and early June when all species were occupying nesting territories. 
Table 3. First-egg Dates for Raptor Species Known to Nest on the Hanford Site

\begin{tabular}{|c|c|c|c|c|c|c|}
\hline \multirow[b]{2}{*}{ Species } & \multicolumn{3}{|c|}{ Hanford Site ${ }^{1}$} & \multicolumn{3}{|c|}{ Statewide 2} \\
\hline & $\begin{array}{c}\text { Number of } \\
\text { Records }\end{array}$ & \begin{tabular}{|c|} 
Earliest First- \\
egg Date
\end{tabular} & $\begin{array}{l}\text { Latest First- } \\
\text { egg Date }\end{array}$ & $\begin{array}{c}\text { Number of } \\
\text { Records }\end{array}$ & $\begin{array}{c}\text { Earliest First- } \\
\text { egg Date }\end{array}$ & $\begin{array}{c}\text { Latest First- } \\
\text { egg Date }\end{array}$ \\
\hline Ferruginous Hawk & - & - & - & 23 & Mar 28 & Apr 30 \\
\hline Swainson's Hawk & 39 & Apr 28 & May 20 & 28 & Apr 28 & May 31 \\
\hline Red-tailed Hawk & 19 & Mar 30 & Apr 20 & 46 & Feb 23 & May 09 \\
\hline Prairie Falcon & 3 & Apr 15 & May 24 & 126 & Mar 09 & May 18 \\
\hline American Kestrel & 4 & May 08 & Jun 18 & 30 & Mar 26 & Jun 20 \\
\hline Northern Harrier & 2 & Apr 07 & Apr 25 & 14 & Mar 26 & May 24 \\
\hline Bald Eagle & - & - & - & 26 & Mar 01 & May 10 \\
\hline Osprey & - & - & - & 26 & Apr 16 & Jun 21 \\
\hline Great Horned Owl & 5 & Mar 05 & Apr 27 & 28 & Feb 11 & Apr 28 \\
\hline Long-eared Owl & 7 & Mar 20 & May 21 & 41 & Mar 06 & Jun 03 \\
\hline Short-eared Owl & - & - & - & 7 & Mar 18 & May 30 \\
\hline Burrowing Owl & 6 & Apr 08 & - & 12 & Mar 23 & Jun 08 \\
\hline Barn Owl & - & - & - & 6 & Mar 04 & May 14 \\
\hline
\end{tabular}

${ }^{1}$ Fitzner et al. 1981

${ }^{2}$ The Burk Museum, University of Washington 2013

\subsection{Methods}

Nests were located using foot and vehicular surveys. Surveys were conducted on the DOE-RL managed lands of the Hanford Site excluding portions of the 200 Area (Figure 1). DOE-RL managed lands include central Hanford, McGee Ranch and Riverland areas, the dunes area, and the southern shoreline of the Columbia River. The 200 Area was not surveyed extensively due to time constrains; there are numerous buildings and elevated structures and many restricted zones in the 200 Area. All elevated substrates in the surveyed areas were searched for nests. Suitable nesting structures included trees, cliffs and rock outcrops, utility poles and transmission towers, abandoned buildings, and nest platforms. The distribution of nesting substrates on DOE-RL managed portions of the Hanford Site is provided in Figure 2. Nest searches occurred in late May and early June when all species occupy nesting territories. Some nest sites were also recorded during other unrelated ecological surveys. A nest was considered occupied if adult birds were tending a recently built nest or eggs or young were present. A Trimble Global Positioning System (GPS) with sub-meter accuracy was used to record nest site coordinates. Coordinates for nest sites not easily accessible in the field, such as high cliffs, were later adjusted on maps in a Geographic Information System (GIS). Field personnel spent as little time as possible at each nest site to avoid disturbing the birds. During cold or wet weather, field personnel avoided flushing incubating adult birds. Flushing adult birds at this time may cause nest failures. Nest searches were not conducted during inclement weather. 


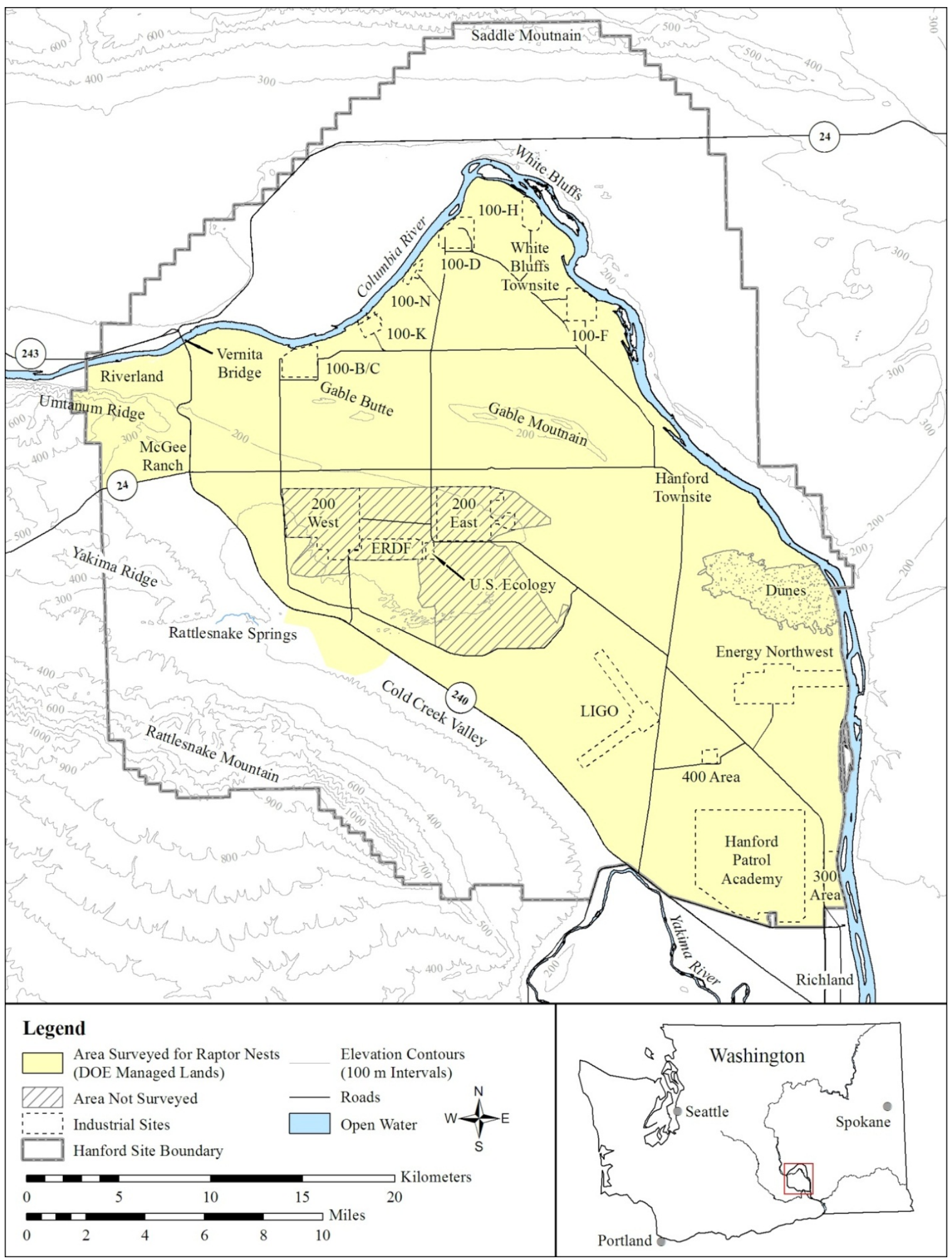

Figure 1. Area Surveyed for Raptor Nests on DOE-RL Managed Lands of the Hanford Site in 2013 
HNF-56769

Revision 0

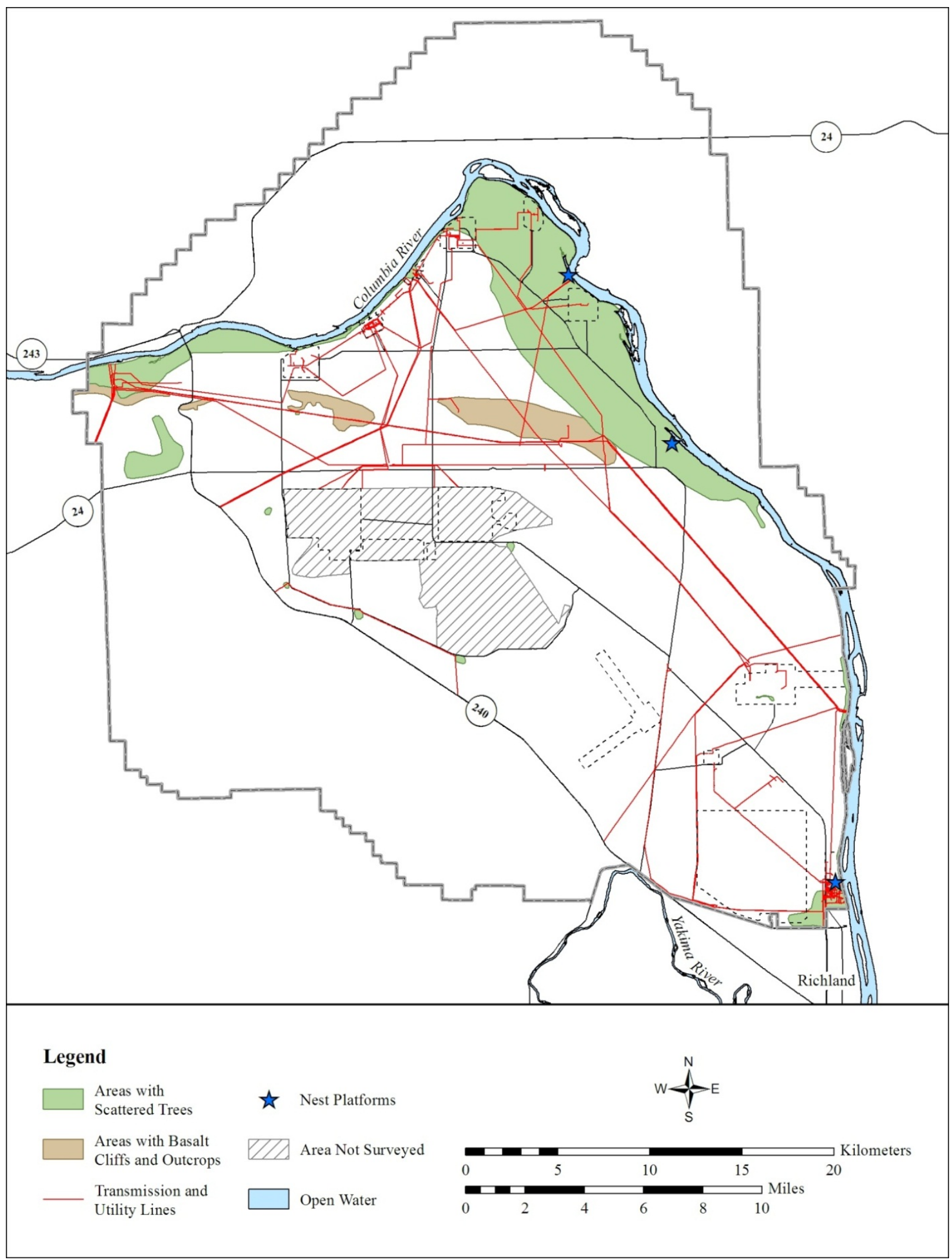

Figure 2. Distribution of Nesting Substrates on DOE-RL Managed Lands of the Hanford Site 
HNF-56769

Revision 0

\subsection{Results}

Nest surveys were conducted on 11 days from May 16, 2013 through June 6, 2013 (May 16, May 20-23, May 28-30, and June 3-6). A total of 115 nest sites were recorded in 2013 including 3-Ferruginous hawks, 15-Swainson's hawks, 14-Red-tailed hawks, 3-Prairie Falcons, 1-American Kestrel, 3-Ospreys, 5-Great Horned Owls, 2-Barn Owls, 2-Long-eared Owls, 1-Bald Eagle, and 66-Common Ravens. Nest substrates used by raptors and ravens on DOE-RL managed lands are shown in Table 4. Approximately seven percent of the raptor and raven nests located in 2013 were on naturally occurring substrates such as cliffs and non-planted trees along the Columbia River. All raptor nest sites located in 2013 are displayed in Figure 3. Common Raven nest sites found in 2013 are shown in Figure 4.

Table 4. Nest Substrates Used by Raptors and Ravens on DOE-RL Managed Lands of the Hanford Site in 2013

\begin{tabular}{|c|c|c|c|c|c|c|c|c|c|}
\hline Species & Tree & Cliff & $\begin{array}{c}\text { Transmission } \\
\text { Tower }\end{array}$ & $\begin{array}{c}\text { Utility } \\
\text { Pole }\end{array}$ & \begin{tabular}{|c|} 
Nest \\
Platform
\end{tabular} & $\begin{array}{c}\text { Instrument } \\
\text { Tower }\end{array}$ & $\begin{array}{c}\text { Communications } \\
\text { Tower }\end{array}$ & Building & Total \\
\hline Ferruginous Hawk & & & 3 & & & & & & 3 \\
\hline Swainson's Hawk & 14 & & & 1 & & & & & 15 \\
\hline Red-tailed Hawk & 3 & 2 & 8 & & & & & 1 & 14 \\
\hline Prairie Falcon & & 3 & & & & & & & 3 \\
\hline American Kestral & 1 & & & & & & & & 1 \\
\hline Bald Eagle & 1 & & & & & & & & 1 \\
\hline Osprey & & & & & 3 & & & & 3 \\
\hline Great Horned Owl & 4 & & & & & & 1 & & 5 \\
\hline Long-eared Owl & 2 & & & & & & & & 2 \\
\hline Barn Owl & & & & & & & & 2 & 2 \\
\hline Common Raven* & 12 & 1 & 44 & 8 & & 1 & & & 66 \\
\hline Total & 37 & 6 & 55 & 9 & 3 & 1 & 1 & 3 & 115 \\
\hline
\end{tabular}

*Common Ravens are not technically raptors but occupy a similar ecological niche. 
HNF-56769

Revision 0

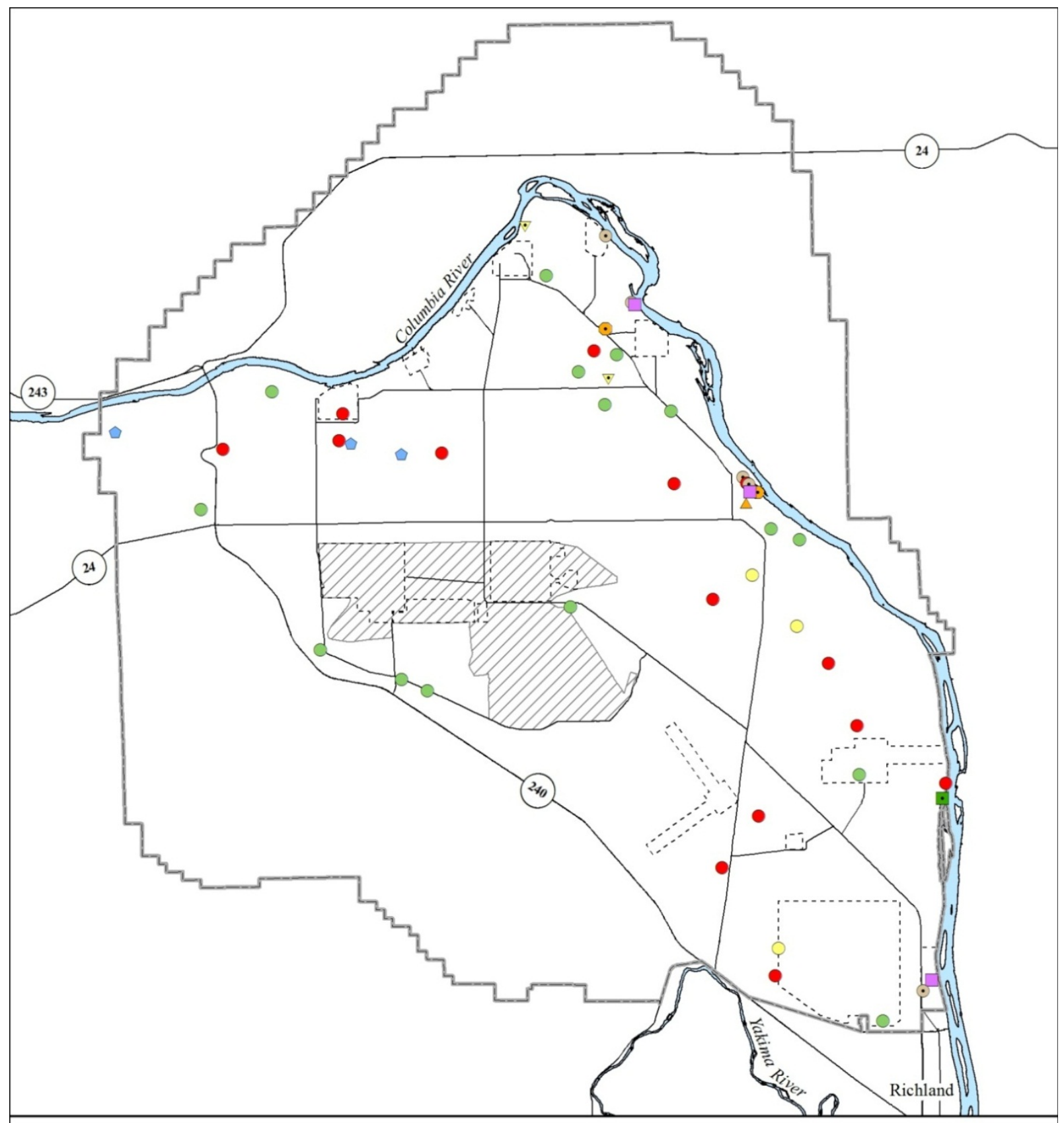

Legend

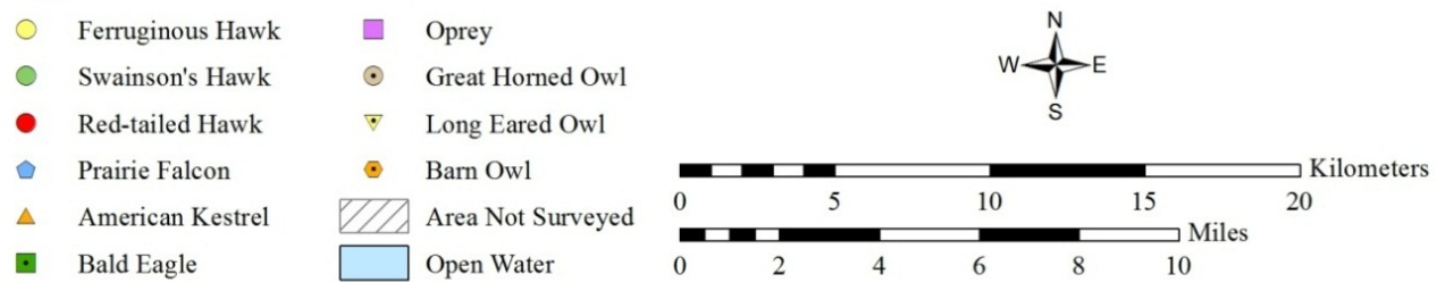

Figure 3. Raptor Nests Located on DOE-RL Managed Lands of the Hanford Site in 2013 
HNF-56769

Revision 0

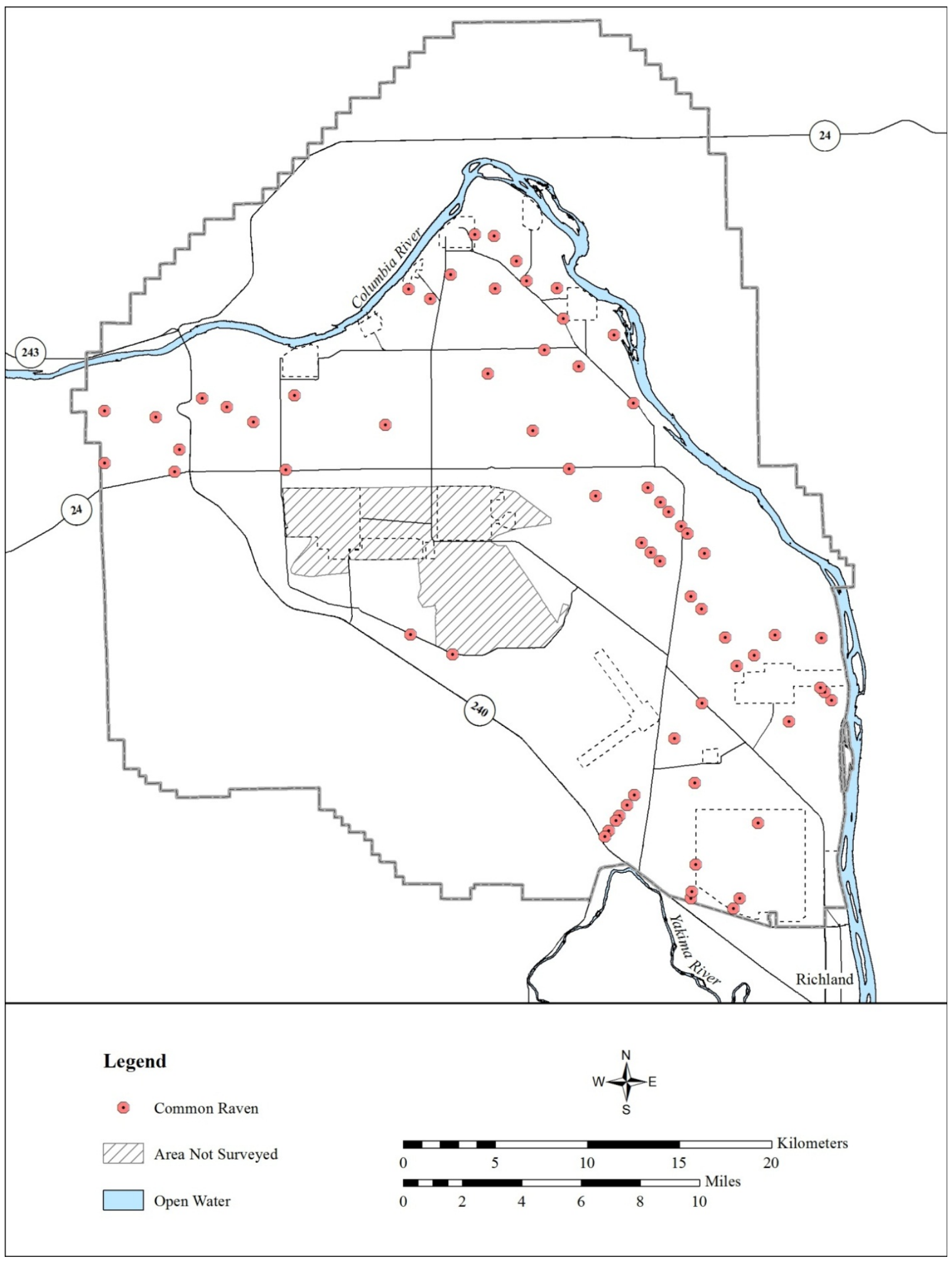

Figure 4. Common Raven Nests Located on DOE-RL Managed Lands of the Hanford Site in 2013 
HNF-56769

Revision 0

\subsection{Discussion}

Survey methods used in 2013 were consistent with the methods used in 2012 (Nugent et al. 2013). Nests of 10 raptor species (Ferruginous hawks, Swainson's hawks, Red-tailed hawks, Prairie Falcons, American Kestrel, Bald Eagles, Ospreys, Great Horned Owls, Long-eared Owls, and Barn Owls), as well as Common Ravens, were located in 2013. Nests of three additional species of raptors (Bald Eagle, Longeared Owls, and Barn Owls) were detected in 2013 over that detected in 2012. For raptor species that were found in both 2012 and 2013, the number of nest sites was similar (Figure 5). The number of Common Raven nest sites was also comparable with 63 nests observed in 2012 and 66 nests observed in 2013. It is likely that all or most of the nests on the DOE-RL managed portions of the Hanford Site of these species (except American Kestrels) were detected during the 2013 survey.

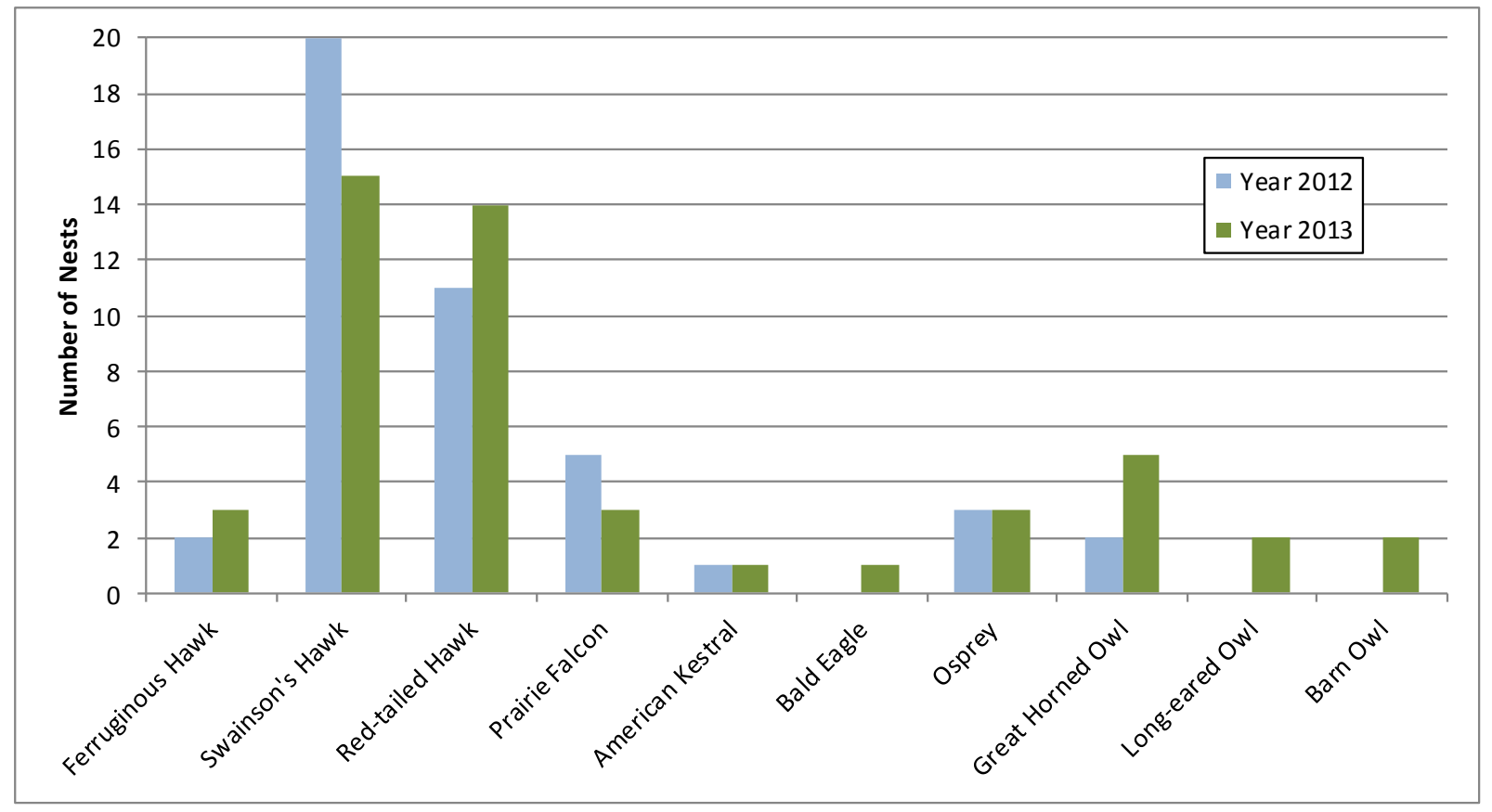

Figure 5. Number of Nest Sites by Raptor Species Located on DOE-RL Managed Lands of the Hanford Site in 2012 and 2013

A successful Bald Eagle nest was documented on the Hanford Site for the first time in 2013. A pair of eagles was observed constructing a nest in a grove of tree on the Hanford shoreline near the upstream end of Wooded Island on January 25. Nest surveys continued at the location regularly and two young were observed in the nest (Figure 6). The two young fledged and were seen alive in the general area in mid-June. 


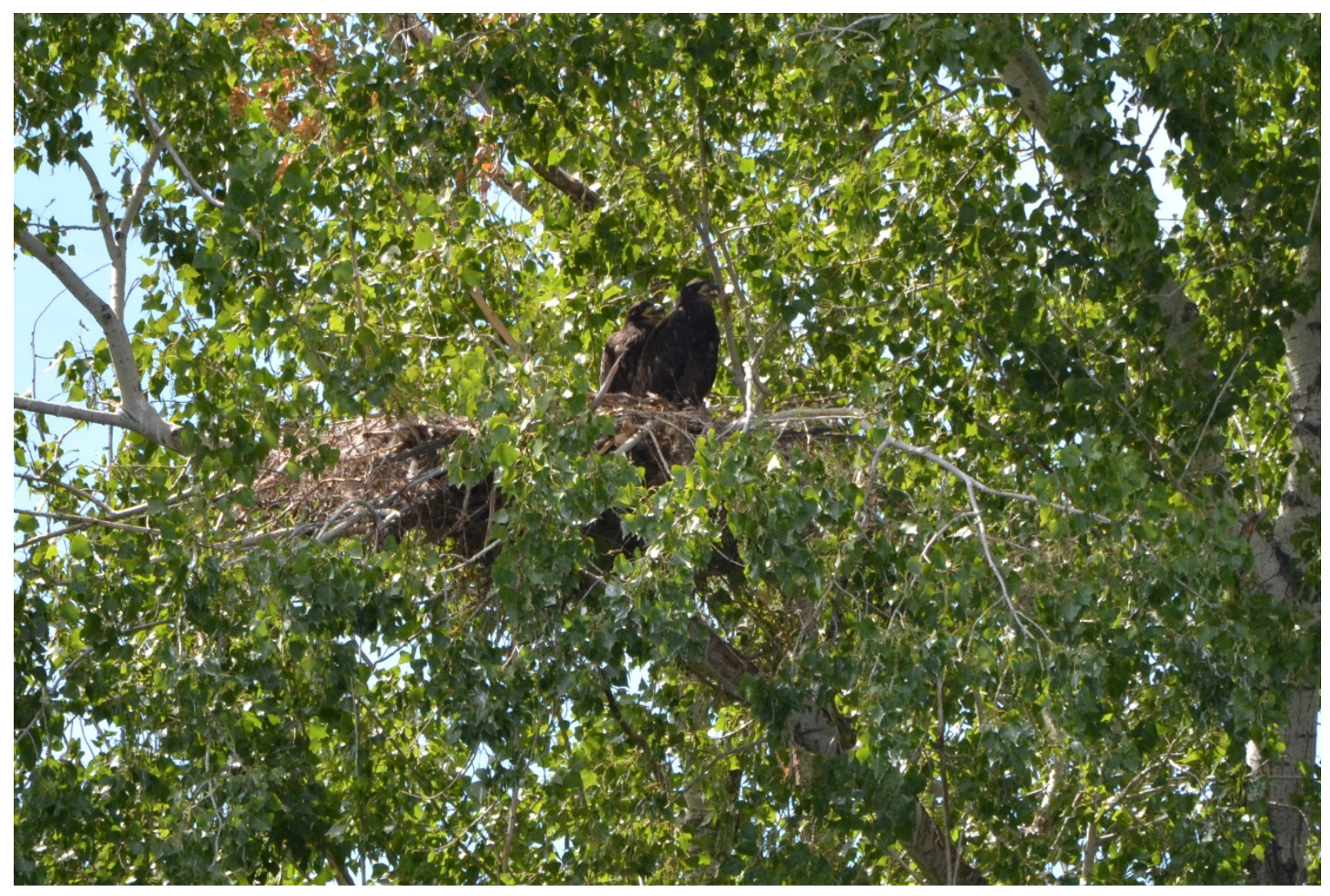

Figure 6. Two Young Bald Eagles in Nest Near Wooded Island, Hanford Site June 27, 2013

Photo by J. Wilde

The number of Buteo hawk nests remained constant from 2012 to 2013 (33 in 2012 and 32 in 2013) though the number of Swainson's hawk nests decreased while the number of Ferruginous and Red-tailed hawk nests increased. Three Ferruginous hawk nests were located in 2013; all were found on $230 \mathrm{kV}$ transmission towers. Two of these nests were situated in the same transmission towers as in 2012. The third nest was located in a transmission tower that has been frequently used in the past. Although adult Ferruginous hawks were seen at this nest site at different times throughout the breeding season, it was unclear if they were actively defending the territory and no young were ever observed in or near the third nest. Nesting Ferruginous hawks were uncommon on the Hanford Site prior to 1987 with only one or two pairs nesting each year. At that time, their presence was limited to basalt outcroppings on the side hills of Rattlesnake Mountain (Fitzner and Newell 1989). Olendroff (1973) found no Ferruginous hawks nesting on the Hanford Site although he suggested that many excellent sites were available. He speculated that the absence of nesting Ferruginous hawks on the Hanford Site may be the result of low numbers of large mammals such as Townsend's ground squirrel (Urocitellus townsendii), black-tailed jackrabbits (Lepus californicus), and cottontail rabbits (Sy/vilagus nuttallii). Fitzner et al. (1981) reported one active nest on the Hanford Site (1975 through 1978) but the presence of several old nests on Gable Butte and Rattlesnake Mountain indicated that more birds were present 10 to 20 years prior. 
In the late 1980s, Fitzner and Newell (1989) documented what they termed an "invasion" of nesting Ferruginous hawks on the Hanford Site. In 1987, four pairs of Ferruginous hawks were observed nesting on the relatively new $230 \mathrm{kV}$ transmission towers associated with the Washington Public Power Supply System reactors (now known as Energy Northwest). Construction of the transmission towers began in 1976 and lines were energized between December 1976 and July 1981. In 1988, seven Ferruginous hawk nests were observed on $230 \mathrm{kV}$ transmission towers and one in a tree, which was believed to have been built after the nest's occupants abandoned a nest in a nearby $230 \mathrm{kV}$ transmission tower (high winds blew nesting material from the tower). Fitzner and Newell (1989) theorized that the influx of nesting Ferruginous hawks was most likely adult birds that had previously nested in nearby areas such as Esquatzel Coulee and the Juniper Dunes in Franklin County and Badger Slope/Horse Heaven Hills in Benton County.

In 1991, 1992, and 1993, 11-active Ferruginous hawk nests were reported on the entire Hanford Site ( 8 to 10 active nests in the area of our survey) each year (Fitzner et al. 1994; Nugent 1995). The majority of these nests were located on transmission towers. Leary et al. (1998) used radio-telemetry to track male Ferruginous hawks nesting on the Hanford Site in 1994 and 1995. They found that the male birds occupied large home ranges and spent much of their time long distances from their nests hunting in irrigated agricultural fields adjacent to the Hanford Site. Their findings may suggest that prey were less available in habitats near the nests and more available in the irrigated fields. They also observed female Ferruginous hawks hunting when their young were only two weeks old, also suggesting lack of food sources. Leary et al. (1996) also documented gulls (Larus spp.) in the diet of Ferruginous hawks at three nests on the Hanford Site in 1994 and 1995, a third indication that food may have been scarce.

A steady decrease in the number of nesting Ferruginous hawks on the Hanford Site has occurred since the 1990s. Clayton (2005) reported four nesting pairs on transmission towers in 2005 and Washington Department of Fish and Wildlife (Per. Comm. M. Livingston, WDFW, April 11, 2012) documented only two nesting pairs on transmission towers in 2010.

Ferruginous hawks are especially sensitive to human disturbance and incursion into their nesting areas. On the Hanford Site, nesting Ferruginous hawks are protected using WDFW guidelines (WDFW 2004). Buffer zones of 1000 meters $(\mathrm{m})$ [3281 feet $(\mathrm{ft})$ ] are established around active nests. Road closure signs

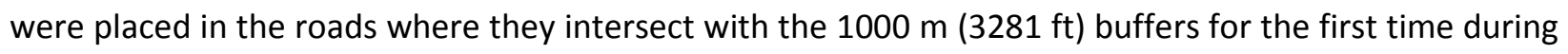
2012. Nest areas are protected from all human disturbance within $250 \mathrm{~m}(820 \mathrm{ft}$ ) between March 1 and May 31 and $1000 \mathrm{~m}$ for prolonged (>0.5 hours) activities during the entire nesting and fledging season (March 1 to August 15). The data collected during this survey allows for the identification and protection of nesting Ferruginous hawks.

Fifteen Swainson's hawk nests were found in 2013, which was down from the 20 nests detected in 2012. The majority of nests were found in small trees associated abandoned homesteads, townsites, and previous army encampment sites. Olendorff (1973) found ten Swainson's hawk nests on the Hanford Site in 1973, all of which were located in "man-created situations." He suggested that Swainson's hawks must have been excluded from the Hanford Site prior to the settlement of Europeans in the area in the 
late 1800s. Fitzner et al. (1981) agreed with this assessment. They found 15 to 18 nesting pairs of Swainson's hawks on the entire Hanford Site each year between 1975 and 1978 (14 to 16 nesting pair in the area of our study). During intensive surveys in 1987, Poole et al. (1988) located 36 occupied Swainson's hawk nest territories on the entire Hanford Site (23 occupied nest territories in the area of our survey). Nugent (1995) found 22 and 25 Swainson's hawk nests on the entire Hanford Site in 1991 and 1992 respectively (14 Swainson's hawk nests each year in the area of our study). Clayton (2005) located nine Swainson's hawk nests in the area of our study in 2005.

Fourteen Red-tailed hawks nests were located in 2013 which was an increase from the 11 nests detected in 2012. In 1973, Olendorff (1973) located 12 Red-tailed hawk nests on the Hanford Site (9 in the area of our study). From 1975 to 1977, Fitzner et al. (1981) reported a dramatic increase in nesting Red-tailed hawks on the Hanford Site from 9 to 25 nests ( 7 to 19 in the area of our study). Nugent (1995) observed 20 Red-tailed hawk nests in 1991 and 25 in 1992 on the entire Hanford Site (13 nests in our study area each year). Clayton (2005) found 14 Red-tailed hawks nests in the area of our study in 2005.

Three Prairie Falcon nests were found in 2013 which was less than the five nests located in 2012. All nests were found along the basalt cliffs of Gable Butte and Umtanum Ridge. The number and location of Prairie Falcon nests on the Hanford Site has remained relatively constant over the years. Olendroff (1973) observed seven Prairie Falcon nests along this stretch of cliffs from Gable Butte to the Yakima-Benton County Line in 1973 while Fitzner et al. (1981) found no more than four pairs nesting in any one year (1975 through 1978) on the entire Hanford Site. In 1973, Olendroff (1973) observed an eyrie in a cavity on the basalt cliffs of Umtanum Ridge which was also occupied in the early 1960s. He speculated that this cavity was used "for decades, if not centuries." In 2012 and 2013, Prairie Falcons were observed using a nest site on Gable Butte that Olendroff also described being used in 1973. Olendroff described the nest site as "there is an old road (actually a trail) into the little valley, but it has not been used for years; hopefully it will remain unused, since the eyrie is secluded, picturesque and 'one of a kind' in the Gable Butte-Gable Mountain region." The site remains today as he described it.

Only one American Kestrel nest was found in 2013. The nest was located in a tree in the Hanford Townsite. Kestrels are secondary cavity nesters and many nests were probably undetected during our surveys.

Ospreys were observed nesting on the Hanford Site for the first time in 2000 (Poston et al. 2001). Similar to 2012, three Osprey nests were found in 2013: one in the 300 Area, one in the Hanford townsite, and one near the White Bluffs boat launch. All three nests were situated on nest platforms built for their use.

Five Great Horned Owls nests were detected in 2013, an increase from the two found in 2012. Four nest sites were found in trees adjacent to the Columbia River, one near the 100-H Area, one near the White Bluffs boat launch and two in the Hanford townsite. An additional nest was situated in a communications tower in the 300 Area. Fitzner (1981) described Great Horned Owls as "not abundant 
HNF-56769

Revision 0

on the Hanford Site, due to the scarcity of heavily wooded habitats and cliffs." He found five nesting pairs of Great Horned Owls on the entire Hanford Site in 1976 and that number declined to three nesting pairs in 1978.

Two Long-eared Owl nests were located in 2013 (Figure 7); no nests were found in 2012. Olendorff (1973) found one Long-eared Owl nest but believed there may be as many as half dozen nests on the Hanford Site. Fitzner et al. (1981) observed three to eight Long-eared Owl nests a year on the entire Hanford Site from 1975 to 1978.

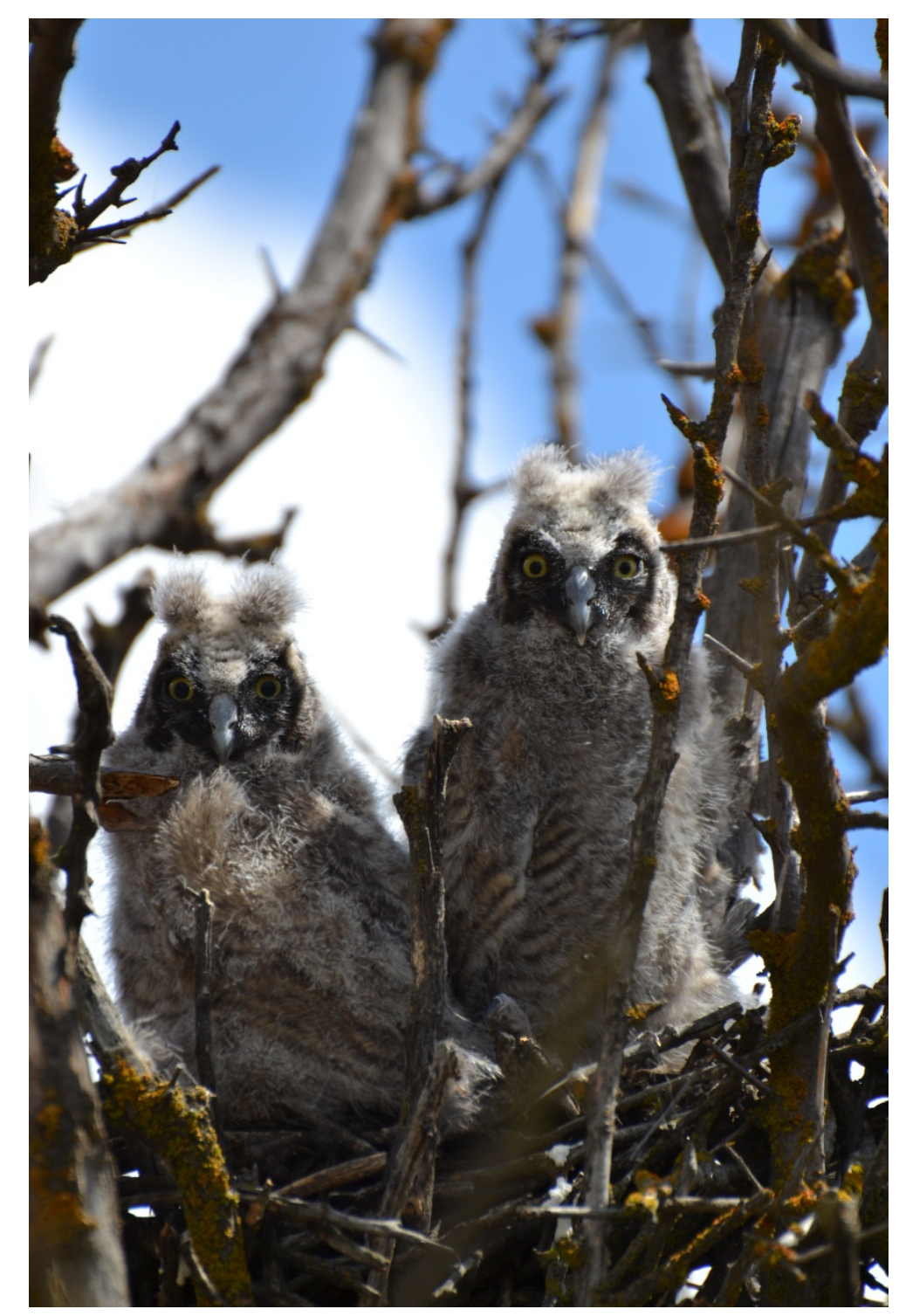

Figure 7. Young Long-eared Owls in Nest Northeast of 100-D Area, Hanford Site May 16, 2013

Photo by C. Lindsey 
HNF-56769

Revision 0

Two Barn Owl Nests were detected in 2013; none was observed in 2012. Barn Owl nest numbers have always been infrequent on the Hanford Site. Fitzner et al (1981) documented two Barn Owl nests each year from 1975 to 1978.

No Short-eared Owl nests were detected in 2012 or 2013. A single adult Short-eared Owl was observed south of Army Loop Road on June 10, 2013 during a Burrowing Owl survey, offering the possibility that this species continues to nest on the Hanford Site.

No Burrowing Owl nests were detected in 2012 or 2013 using the above survey methods. However, nest burrows were found on the Hanford Site in 2012 and 2013 under different monitoring efforts (Wilde et al. 2012, and Wilde et al. 2014). A total of 50 active burrows were observed on DOE-RL managed lands of the Hanford Site in 2013, up from the 39 active burrows found 2012.

Nesting Common Ravens appear to have increased significantly on the Hanford Site in recent years. Sixty-six raven nests were located in 2013 and 63 in 2012 compared to 45 nests located by Clayton (2005) in 2005. Only one of 66 nests found in 2013 and three of the 63 nests found in 2012 were on naturally occurring cliff substrates. The majority of raven nests were found on transmission towers or utility poles.

Nesting raptors and ravens have clearly benefited from the introduction of anthropogenic nest structures (e.g., transmission towers, utility poles, planted trees) on the Hanford Site. Although some nesting pairs may have used other available nesting substrates, in the absence of current anthropogenic sources, it is certain that the total number of raptors would be significantly less without these artificial nesting locations. It is unclear what impacts artificially high nesting populations of raptors and ravens have on prey species such as ground squirrels, jackrabbits, and Greater Sage-Grouse (Centrocercus urophasianus), but the prevalence of raptors on the Hanford Site and the low levels or complete lack of these prey species is compelling. Determining the impact to these prey species may be an area of future research. The above described protocol is currently planned to continue on an annual basis to document the distribution and abundance and prevent the disturbance or other impacts to nesting raptors on the DOE-RL managed portions of the Hanford Site.

\subsection{References}

Burke Museum. 2013. Washington Birds Breeding Phenology Project. University of Washington. Accessed 10/30/2013: http://www.burkemuseum.org/ornithology/phenology.

Clayton, K. M. 2005. Breeding Population Status and Nest Site Characterization of Hawks (Buteo spp.) and Common Ravens (Corvus corax) on the Hanford Site, Southcentral Washington. PNNL-SA-46396. Pacific Northwest National Laboratory, Richland, Washington.

Comprehensive Environmental Response, Compensation, and Liability Act of 1980, 42 U.S.C. 9601-9675. (P.L. 96-510). 
HNF-56769

Revision 0

Dirkes R. L. and R. W. Hanf. 1998. Hanford Site Environmental Report for Calendar Year 1997. PNNL-11795. Pacific Northwest National Laboratory, Richland, Washington. Online at: http://msa.hanford.gov/page.cfm/environmentalreports2001-latest.

Dirkes R. L., R. W. Hanf, J. R., and T. M. Poston. 1999. Hanford Site Environmental Report for Calendar Year 1998. PNNL-12088. Pacific Northwest National Laboratory, Richland, Washington. Online at: http://msa.hanford.gov/page.cfm/environmentalreports2001-latest.

Fitzner, R.E., D. Berry, L.L. Boyd, and C.A. Rieck. 1977. Nesting of Ferruginous Hawks (Buteo regalis) in Washington 1974-75. The Condor 79:245-249.

Fitzner, R.E. 1978. The Ecology and Behavior of Swainson's Hawk in Southcentral Washington. PhD thesis. Washington State University. Pullman Washington.

Fitzner, R.E. 1980. Behavioral Ecology of the Swainson's Hawk in Southeastern Washington. PNL-2754. Pacific Northwest Laboratory, Richland, Washington.

Fitzner, R. E., W. H. Rickard, L. L. Cadwell, and L. E. Rogers. 1981. Raptors of the Hanford Site and Nearby Areas of Southcentral Washington. PNL-3212. Pacific Northwest National Laboratory, Richland, Washington.

Fitzner, R. E., and R. L. Newell. 1989. Ferruginous hawk nesting on the U.S. DOE Hanford Site: case history of a recent invasion caused by transmission lines. In Proceedings IV: Issues and technology in the management of impacted wildlife. Pp. 125-132. Thorne Ecological Institute, Boulder, Colorado.

Fitzner, R. E., S. G. Weiss, and J. A. Stegen. 1994. Threatened and Endangered Wildlife Species of the Hanford Site Related to CERCLA Characterization Activities. WHC-EP-0513. Westinghouse Hanford Company, Richland, Washington.

Leary, A. W. 1996. Home Ranges, Core Use Areas, and Dietary Habits of Ferruginous Hawks in Southcentral Washingtion. MS Thesis. Boise State University, Boise, Idaho.

Leary, A. W., A. L. Jerman, and R. Mazaika. 1996. Gulls (Larus spp.) in the Diet of Ferruginous Hawks. J. Raptor Res. 30(2):105.

Leary, A. W., R. Mazaika, and M. J. Bechard. 1998. Factors Affecting the Size of Ferruginous Hawk Home Ranges. Wilson Bulletin 110(2):198-205.

National Environmental Policy Act of 1969, 42 U.S.C. 4321, et seq. (P.L. 91-190).

Nugent, J. J. 1995. Nest-Site and Habitat Selection of Buteo Species in Southeastern Washington and the Use of Geographic Information Systems to Model Nest Habitat Quality. MS Thesis. University of Montana, Missoula, Montana.

Nugent, J., C. Lindsey, and G. Malin. 2013. Raptor Nest Monitoring Report for Calendar Year 2012. HNF-53073, Rev. 0. Mission Support Alliance, Richland, Washington. Online at: http://www.hanford.gov/files.cfm/hnf-53073 - rev 00 no coversheets.pdf.

Olendorff, R. R. 1973. Raptorial Birds of the U.S.A.E.C. Hanford Reservation, South-Central Washington. BNWL-1790. Battelle Pacific Northwest Laboratories, Richland Washington. 
HNF-56769

Revision 0

Poole, L. D., N. V. Marr, and S. M. McCorquodale. 1988. Productivity, Mortality, and Response to Disturbance of Nesting Swainson's Hawks on the Hanford Site. PNL-6496. Pacific Northwest National Laboratory, Richland, Washington.

Poston T. M., R. W. Hanf, J. R., and R. L. Dirkes. 2000. Hanford Site Environmental Report for Calendar Year 1999. PNNL-13230. Pacific Northwest National Laboratory, Richland, Washington.

Poston T. M., R. W. Hanf, J. R., R. L. Dirkes, and L. F. Morasch. 2001. Hanford Site Environmental Report for Calendar Year 2000. PNNL-13487. Pacific Northwest National Laboratory, Richland, Washington.

USDOE (U. S. Department of Energy). 1999. Final Hanford Comprehensive Land-Use Plan Environmental Impact Statement. DOE/EIS-0222-F. U.S. Department of Energy, Washington, D.C. Online at: http://energy.gov/nepa/downloads/eis-0222-final-environmental-impact-statement-0

USDOE (U. S. Department of Energy). 2009. Bald Eagle Management Plan for the Hanford Site, SouthCentral Washington. DOE/RL-94-150, Rev. 1. U.S. Department of Energy, Richland Operations Office, Richland, Washington.

USDOE (U. S. Department of Energy). 2013. Hanford Site Biological Resources Management Plan. DOE/RL-96-32, Rev. 1. U.S. Department of Energy, Richland Operations Office, Richland, Washington.

WDFW (Washington Department of Fish and Wildlife). 2004. Management Recommendations for Washington's Priority Species - Volume IV: Birds. Washington Department of Fish and Wildlife, Olympia, WA.

WDFW (Washington Department of Fish and Wildlife). 2013. Species of Concern in Washington. Washington Department of Fish and Wildlife. Online at: http://wdfw.wa.gov/conservation/endangered/

Wiggins, D. A., D. W. Holt and S. M. Leasure. 2006. Short-eared Owl (Asio flammeus), The Birds of North America Online (A. Poole, Ed.). Ithaca: Cornell Lab of Ornithology; Retrieved from the Birds of North America. Onlineat: http://bna.birds.cornell.edu/bna/species/062doi:10.2173/bna.62

Wilde, J., C. Lindsey, J. Nugent and M. Sackschewsky. 2012. Burrowing Owl Monitoring Report for Calendar Year 2012. HNF-54294 Rev. 0, 2012. Mission Support Alliance, Richland, Washington. Online at: http://www.hanford.gov/files.cfm/hnf-54294 - rev 00 cleared public.pdf.

Wilde, J, C. Lindsey, J. Nugent and M. Filan. 2014. Hanford Site Burrowing Owl Monitoring Report for Calendar Year 2013. HNF-56531. Mission Support Alliance, Richland, Washington. 